\title{
Integral treatment of butt joints for the fatigue life assessment in the low cycle fatigue regime
}

\author{
Benjamin Möller ${ }^{1}$
}

Received: 26 December 2019 / Accepted: 28 September 2020 / Published online: 23 October 2020

(C) The Author(s) 2020

\begin{abstract}
The framework for a fatigue assessment of welded joints under service loading conditions of crane structures from the low cycle to the high cycle fatigue regime includes the consideration of elastic-plastic material behavior, variable amplitude loading, and acceptable calculation times. Therefore, an integral treatment of butt joints has been developed for fatigue life estimation. The butt weld is considered in its entirety, so that it can be described by its cyclic behavior. The evaluation of the cyclic stress-strain behavior and tri-linear strain-life curves of butt joints for different high-strength, fine-grained structural steels, derived by straincontrolled fatigue tests, is the basis for this description. This procedure is not limited to conventionally applied gas metal arc welding only, but also the fatigue assessment of laser beam welding is possible, for example. Cyclic transient effects have been analyzed and a distinctive cyclic softening is described by linearization of Ramberg-Osgood parameters, depending on the damage content of each cycle derived from constant amplitude, strain-controlled tests. On the basis of the cyclic behavior in combination with memory and Masing behavior, a simulation of the stress-strain paths of investigated butt welds, under constant and variable amplitude loading, has been performed. Damage parameters are used to accumulate the damage cycle by cycle in order to derive the fatigue lifetime. Finally, calculated fatigue lives were compared with experimentally determined lives, showing the impact of this procedure.
\end{abstract}

Keywords Integral treatment $\cdot$ Welded joint $\cdot$ Butt weld $\cdot$ Cyclic behavior $\cdot$ Damage parameter $\cdot$ Fatigue life estimation

\section{Introduction}

In the design and manufacture of modern steel assemblies, permanent joining by welding is still common. The crane industry makes use of gas metal arc welding (GMAW), i.e., metal active gas welding, as a traditional and prevalent welding process, e.g., for the manufacture of truck and crawler cranes. Due to recent process developments, laser beam welding and the hybrid combination of laser beam and gas metal arc welding have appeared as expedient alternatives. However, for applications with highly stressed structures, as in the case of loading situations of the telescopic boom of

Recommended for publication by Commission XIII - Fatigue of Welded Components and Structures

Benjamin Möller

benjamin.moeller@lbf.fraunhofer.de

1 Department "Materials and Components", Fraunhofer Institute for Structural Durability and System Reliability LBF,

Darmstadt, Germany truck cranes, for example, Fig. 1a, the service loads are related to the low cycle fatigue regime. Within such structures, butt joints are essential load-carrying welds (Fig. 1b). Therefore, the following points need to be considered in the fatigue estimation:

- In highly stressed areas, welded joints are limiting factors in design, e.g., butt joints in the telescopic boom

- Crane-specific load scenarios result in variable amplitude loading (VAL) and elastic-plastic stresses and strains (LCF)

- A large number of load cases requires a method for fatigue life estimation that is easy to use

The fatigue assessment of welded joints according to recommendations and standards, Eurocode 3 [3], the crane design standard DIN EN 13001-3-1 [4], Hobbachers IIW recommendations [5], and the FKM guideline [6], is based on fatigue classes (FAT), i.e., characteristic stress ranges $\Delta \sigma_{\mathrm{C}}$ at 2 . $10^{6}$ cycles to failure. These FAT classes were derived from 
Fig. 1 a Truck crane on the test site (photo from [1]) and $\mathbf{b}$ representation of a transverse butt weld in the tensile-stressed upper shell [2]
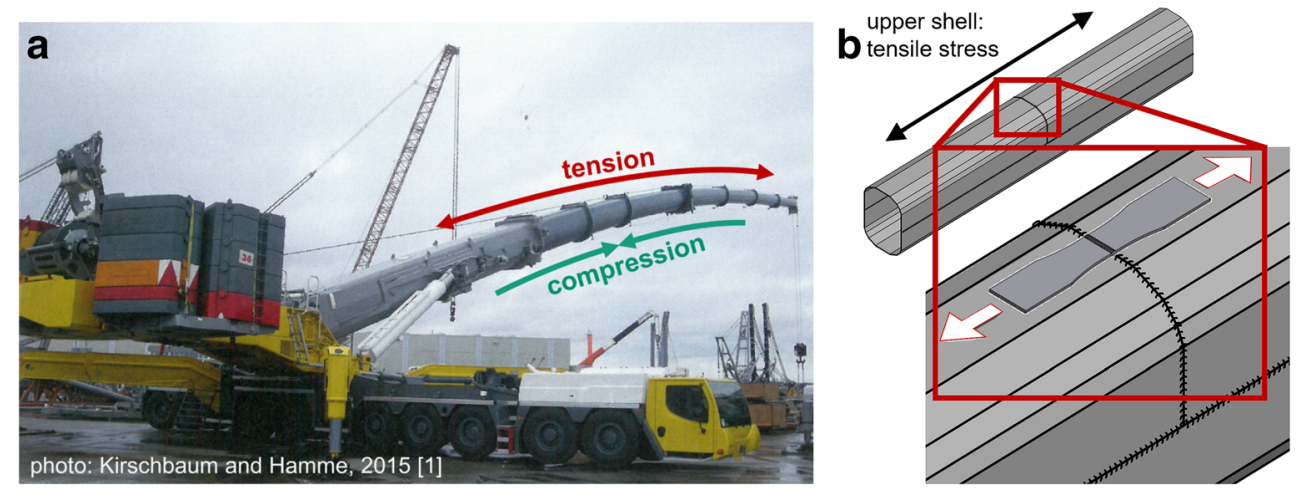

experimental results from specimens and components. Specimens for experimental fatigue investigations of steel structures with medium sheet thickness, i.e., $5 \mathrm{~mm}$ to approximately $20 \mathrm{~mm}$, are usually of larger scale and tested under stress control to verify the fatigue assessment and FAT classes. To date, these fatigue recommendations are mostly limited to steels with a maximum yield strength of $960 \mathrm{MPa}$ and the assessment by FAT classes does not include the low cycle fatigue (LCF) regime and elastic-plastic material behavior. Therefore, they are restricted to cycles to failure of $\mathrm{N} \geq 1 \cdot 10^{4}$.

An overview of the fatigue design concepts, which are applied in the assessment of welded joints, is given in Fig. 2 and, in more detail, by Radaj et al. [8,9]. The nominal stress (and strain) approach requires the definition of a nominal stress or strain, i.e., a reference cross-section, and assignment of a specific notch detail. FAT values for nominal stress and various notch details have been defined [3-6]. Even though FAT classes are defined for survival probabilities of $97.7 \%$, analyses of fatigue results of butt welds, including data points for $\mathrm{N}_{\mathrm{f}}<5 \cdot 10^{4}$ from Olivier and Ritter [10], Leitner et al. [11], Berg and Stranghöner [12], and Möller [2] have found that the assessment by FAT 90 (or even FAT 80/FAT 71) tends to be unsafe at high loading levels in and close to the LCF regime.

In the case of more complex structures, where it is not possible to define nominal stress, the structural stress (or strain) concept can be applied, as further described by the IIW recommendations of Hobbacher [5] and Fricke [13] as well as [8], where FAT classes for structural stresses can also be found. Due to the linear-elastic extrapolation, which is used in most of the concept variants, the existing stress concentration at the notch and notch support effects at this location are not captured. Furthermore, structural stress and strain concepts reveal their limitations when confronted with root notches.

As a consequence and in addition to the nominal and structural stress (or strain) concepts, local concepts (cf. [5, 7-9, 13]) are increasingly used for the design of welded joints. FAT classes for notch stresses result in fictitious (linearelastic) stresses at the notch root. The notch stress approaches attracted wide interest and developed over recent decades, so that they are a useful assessment approach for welded joints, especially in the case of the reference radius concept (cf. [8, 13]). However, this approach cannot be applied in elasticplastic stress-strain states, as is the case in the LCF regime or, rather, in the notch root of a weld for high loading applications. In order to cover this case, the notch strain concept (cf. $[5,7-9,13]$ ) is used, where the cyclic material behavior forms the basis for the simulation and assessment of the stressstrain state in the notch, in addition to the geometry of the joint, as introduced by Lawrence et al. [14]. The effort involved in such an assessment should not be underestimated and increases further, if transient effects and microstructural differences, as given by investigations on the effect of the microstructure of the different weld zones on the fatigue
Fig. 2 Overview of fatigue design concepts for welded joints [7]
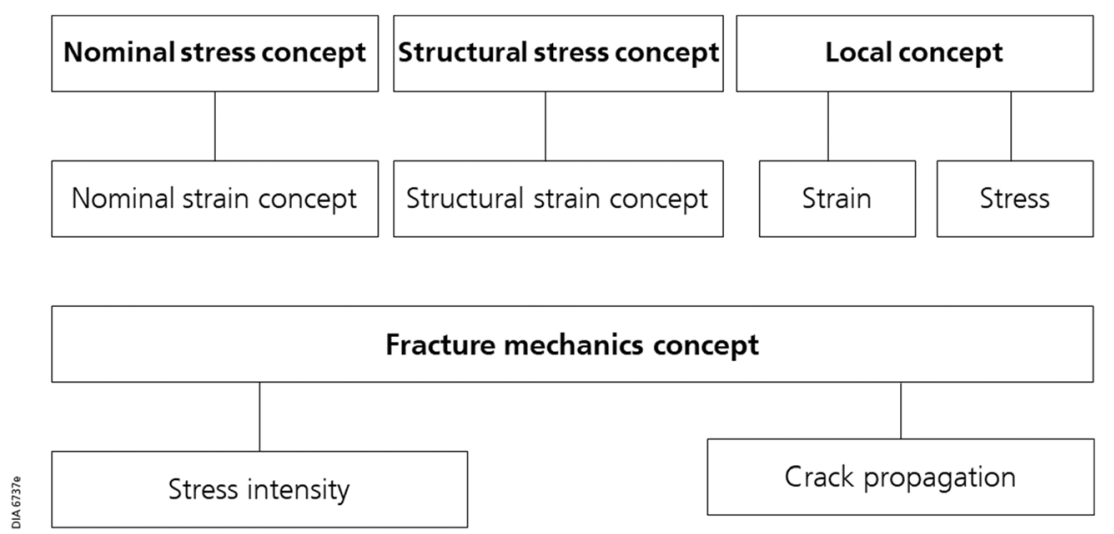
strength from various authors [15-20], are taken into account. Recent work of Saiprasertkit et al. [21-24] uses an analytical approximation for the description of the effective notch strain from the notch strain concept with a reference radius of $r_{\text {ref }}=$ $1.00 \mathrm{~mm}$ in the case of load-carrying cruciform joints to show a conservative estimation of FAT 200 within the LCF and HCF regimes. On the contrary, this work aims at providing a fatigue life estimation by an integral treatment of butt welds under low to high constant and variable amplitude loading for elastic-plastic stress-strain conditions with moderate effort, as described in this paper.

Finally, fracture mechanics concepts, e.g., stress intensity or crack propagation approaches, assume a pre-existing cracklike defect for the life assessment, but will not be in the focus of this work.

\section{Materials and welding process}

Based on unalloyed structural steels [25] and normalized rolled fine-grained structural steels $(\mathrm{N}, \mathrm{NL})$ [26] with yield strengths $\mathrm{R}_{\mathrm{eH}}$ or $\mathrm{R}_{\mathrm{p} 0.2}$ of 235 to $460 \mathrm{MPa}$, the steel designation for high-strength, fine-grained structural steels according to [27] is also based on the minimum yield strength. In a further subdivision, a distinction can be made between high-strength $\left(\mathrm{R}_{\mathrm{p} 0.2} \leq 960 \mathrm{MPa}\right)$ and ultra-high-strength $\left(\mathrm{R}_{\mathrm{p} 0.2}>960 \mathrm{MPa}\right)$ fine-grained structural steels. The yield strength specification is followed in the designation by information on the manufacturing process. A basic distinction is made between water quenched and tempered (Q, QL) [28] and thermomechanically treated (M, TM) [29] steels. In the context of this work, the S960QL (material no.: 1.8933), two thermomechanically rolled products of grade S960M (manufacturer "1" and "2") and the ultra-high-strength S1100QL (material no.: 1.8942) fine-grained structural steel, suitable for welding, have been investigated. Starting from a conventional hot rolling above the recrystallization temperature of austenite, followed by normalizing annealing in normalized steels, water quenched and tempered steels are rapidly cooled in water, resulting in very good strength properties due to the bainitic and martensitic microstructure [30]. Microstructural transformations by subsequent tempering can, above all, improve their toughness properties. Thermomechanical rolling, i.e., a combined mechanical-thermal rolling process, which is partially carried out below the recrystallization temperature, comprises a large number of process variants (e.g., accelerated cooling), which, together with the alloying concept (microalloy), result in high toughness and strength [30].

The steel materials in this investigation are characterized by the mechanical properties listed in Table 1-yield strength $R_{p 0.2}$, tensile strength $R_{m}$, elongation at fracture $A_{5}$, and impact energy KV (at three different temperatures). The characteristic values meet the requirements according to [28]:
- $\quad$ Minimum yield strength: $\mathrm{R}_{\mathrm{p} 0.2} \geq 960 \mathrm{MPa}(\mathrm{S} 960), \mathrm{R}_{\mathrm{p} 0.2} \geq$ $1100 \mathrm{MPa}$ (S1100)

- Tensile strength: $980 \leq \mathrm{R}_{\mathrm{m}} \leq 1150 \mathrm{MPa}$ (S960), $1250 \leq$ $\mathrm{R}_{\mathrm{m}} \leq 1550 \mathrm{MPa}$ (S1100)

- Minimum elongation at fracture: $\mathrm{A}_{5} \geq 10 \%$ (S960)

- Notched bar impact energy: $\mathrm{KV} \geq 40 \mathrm{~J}\left(\mathrm{~S} 960\right.$ at $\left.-20^{\circ} \mathrm{C}\right)$ and $\mathrm{KV} \geq 30 \mathrm{~J}\left(\mathrm{~S} 960\right.$ at $\left.-40{ }^{\circ} \mathrm{C}\right)$

The specifications for the impact energy are temperaturedependent and correspond to the test carried out by the steel manufacturer.

Butt joints were manufactured, using the 8-mm-thick S960QL, S960M, and S1100QL steel sheets described previously, by gas metal arc welding (GMAW), i.e., metal active gas welding, applying the process parameters given in Table 2, as this is the traditionally and commonly used welding process in the crane industry and related areas. A cooling time $t_{8 / 5}$ of 5 to $10 \mathrm{~s}$ is an essential process requirement. For the ultra-high-strength, fine-grained structural steel S1100QL, the use of filler metal G $896 \mathrm{M} \mathrm{Mn4Ni2CrMo} \mathrm{with}$ a minimum yield strength of $\mathrm{R}_{\mathrm{p} 0.2}=890 \mathrm{MPa}$ results in a welded joint with weld areas of lower strength (undermatching), especially in the heat-affected zone (HAZ). The butt joints were created in a multi-layer weld with one weld root, one backing and one or two top layers. Two overlapping top layers have been chosen for manually welded S960M and S1100QL, while a single top layer is used for manually S960QL welds, in order to compare them with a partially automated joining of the steel sheets. Welds, manufactured by manual GMAW, were executed by qualified welders from the crane industry. In the past, efforts were made to introduce automated welding and laser beam welding (LBW) or a combined LBW-GMAW as a joining process, in order to reduce distorsions and increase the strength of joints, i.e., also the fatigue strength. Investigations on the fatigue behavior of these welds are still ongoing.

\section{Stress-based fatigue life derived from force-controlled testing}

Fatigue tests on butt joints have been performed on resonance and servohydraulic fatigue test rigs under force control at a load ratio of $\mathrm{R}_{\mathrm{F}}=0.1[31,33,34]$. The specimen was designed to have a free length between the clamping areas of $250 \mathrm{~mm}$. Low test frequencies in the range of $0.1 \mathrm{~Hz} \leq \mathrm{f} \leq 7.0 \mathrm{~Hz}$ were defined for tests based on the "Testing and Documentation Guideline for the Experimental Determination of Mechanical Properties of Steel Sheets for CAE-Calculations" [35] with a focus on low cycle fatigue. The test frequency was reduced with increasing force amplitude to a minimum of $0.1 \mathrm{~Hz}$ and was increased to $35 \mathrm{~Hz}$ for fatigue testing in the high cycle 
Table 1 Mechanical properties of investigated steel grades [31]

\begin{tabular}{|c|c|c|c|c|c|c|}
\hline \multirow[t]{2}{*}{ Material } & \multirow[t]{2}{*}{$R_{\mathrm{p} 0,2}(\mathrm{MPa})$} & \multirow[t]{2}{*}{$R_{\mathrm{m}}(\mathrm{MPa})$} & \multirow[t]{2}{*}{$A_{5}(\%)$} & \multicolumn{3}{|l|}{$K V(\mathrm{~J})$} \\
\hline & & & & $-20{ }^{\circ} \mathrm{C}$ & $-40{ }^{\circ} \mathrm{C}$ & $-60^{\circ} \mathrm{C}$ \\
\hline S960QL & 1042 & 1069 & 11 & n.a. & $43 \pm 8$ & n.a. \\
\hline S960M manufacturer 1 & 1032 & 1121 & 12 & n.a. & $60 \pm 5$ & n.a. \\
\hline S960M manufacturer 2 & 993 & 1041 & 11 & $114 \pm 24$ & $\geq 30[32]$ & $36 \pm 32$ \\
\hline S1100QL & 1224 & 1418 & 12 & $41 \pm 1$ & $37 \pm 1$ & $28 \pm 4$ \\
\hline
\end{tabular}

fatigue (HCF) regime. "Total rupture of the specimen" was defined as the final failure criterion.

The evaluation of the fatigue test results in the HCF regime, both under constant amplitude loading (Wöhler curve) and variable amplitude loading (Gaßner curve) with a random load time history derived from a Gaussian-like load spectrum [34, 36], has been carried out according to the maximum likelihood estimation (MLE) [37], Fig. 3. Both Wöhler and Gaßner curves for butt-welded S960QL, S960M, and S1100QL finegrained steels are evaluated for all steel grades together. In Fig. 3, the lines are represented for survival probabilities of $\mathrm{P}_{\mathrm{S}}=10,50$, and $90 \%$. The Wöhler line is characterized by the slope $k=3.1$, the nominal stress amplitude $\sigma_{\mathrm{a}, \mathrm{n}}\left(\mathrm{N}_{\mathrm{r}}=1\right.$. $\left.10^{6}, \mathrm{P}_{\mathrm{S}}=50 \%\right)=60 \mathrm{MPa}$, and the scatter $\mathrm{T}_{\sigma}=1: 1.98$ - the Gaßner line is, on the other hand, described by $k=4.2, \sigma_{\mathrm{a}, \mathrm{n}}$ $\left(\mathrm{N}_{\mathrm{r}}=1 \cdot 10^{6}, \mathrm{P}_{\mathrm{S}}=50 \%\right)=184 \mathrm{MPa}$, and $\mathrm{T}_{\sigma}=1: 1.56$. Wöhler and Gaßner lines are in good agreement with those of other evaluation methods shown in $[31,33,34]$. This is due to the fact that the evaluation is limited to the HCF and that there are no differences in applying the method of the least squares and the maximum likelihood method including just one run-out. Differentiation between the various test series (combination of base material and welding process) shows a dependence of the fatigue strength on the weld quality and welding process [ 31 , $33,34]$. It has been found that partially automated welding

Table 2 Main process parameters for GMAW of butt joints made of high-strength, fine-grained structural steels

\begin{tabular}{ll}
\hline Process parameter & Specification \\
\hline Welding procedure & Gas metal arc welding (GMAW) \\
Materials & S960QL, S960M, S1100QL \\
Filler metal & G $896 \mathrm{M} \mathrm{Mn4Ni2CrMo}$ \\
Preheating temperature & $80{ }^{\circ} \mathrm{C}$ \\
Working temperature & $80{ }^{\circ} \mathrm{C}$ \\
Cooling time $\mathrm{t}_{8 / 5}$ & 5 to $10 \mathrm{~s}$ \\
Shielding gas & $\mathrm{M} 21$ \\
Number of layers & $3-4(1 \mathrm{root}, 1$ backing, 1-2 top layers) \\
Applied voltage/current/welding speed: \\
Root layer: & $21 \mathrm{~V} / 145 \mathrm{~A} / 6 \mathrm{~m} / \mathrm{min}$ \\
Backing and top layers: & $25-27 \mathrm{~V} / 185-190 \mathrm{~A} / 9 \mathrm{~m} / \mathrm{min}$ \\
\hline
\end{tabular}

results in a reduced misalignment and an increase in fatigue strength. In the LCF regime, force-controlled fatigue testing is sensitive to plasticity and flow, so that small changes in force can have a considerable influence on the fatigue life of the welded joint [19]. This restriction can be counteracted by strain-controlled fatigue testing.

\section{Integral treatment and cyclic behavior of butt welds}

\subsection{Integral treatment of welded joints}

The complexity of and effort in the application of local fatigue assessment approaches increases drastically, if the elasticplastic material model of welded joints is supplemented by a local differentiation of the material behavior and the consideration of transient effects. Therefore, an integral treatment of a butt joint is introduced as a basis for the fatigue life assessment. This integral treatment uses the cyclic material behavior, evaluated from strain-controlled fatigue testing, but characterizes butt welds by the cyclic stress-strain behaviors and strain-life curves with an integral approach from the base material across the weld to the base material (Fig. 4).

\subsection{Cyclic behavior of butt welds}

A servohydraulic test rig with a maximum load of $100 \mathrm{kN}$ has been used for strain-controlled fatigue tests of the small-scale flat specimens (Fig. 5). Although the greater sheet thickness of $8 \mathrm{~mm}$ does not fall within the range of thin sheets, the tests were carried out in accordance with the specifications of SEP1240 [35]. As a result of the strain ratio of $R_{\varepsilon}=-1$, an anti-buckling device is used. Depending on the strain level, the test frequencies were selected as $0.1 \mathrm{~Hz}\left(\varepsilon_{\mathrm{a}, \mathrm{t}}>0.4 \%\right)$, $0.5 \mathrm{~Hz}\left(0.4 \% \geq \varepsilon_{\mathrm{a}, \mathrm{t}}>0.2 \%\right)$, and $4.0 \mathrm{~Hz}\left(\varepsilon_{\mathrm{a}, \mathrm{t}} \leq 0.2 \%\right)$. From the test results, strain-life curves and cyclic stress-strain curves are derived, which describe the cyclic material behavior (base material) and the cyclic behavior of the butt weld. For this purpose, an extensometer with a $25 \mathrm{~mm}$ measuring length was used in the strain-controlled tests. In the case of the butt 

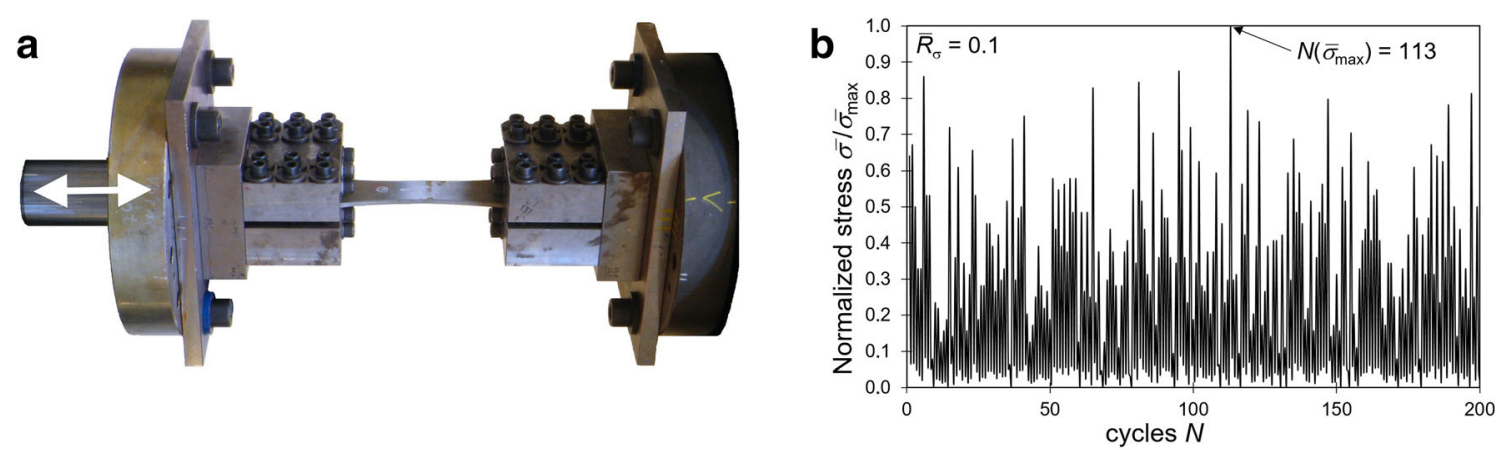

\section{C}

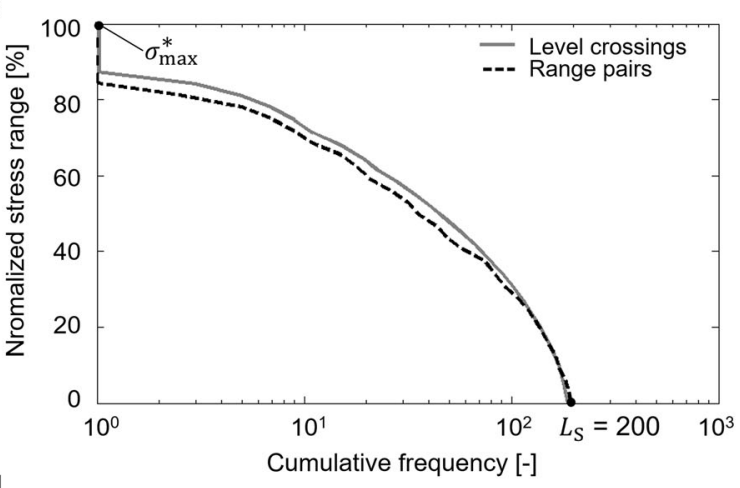

d

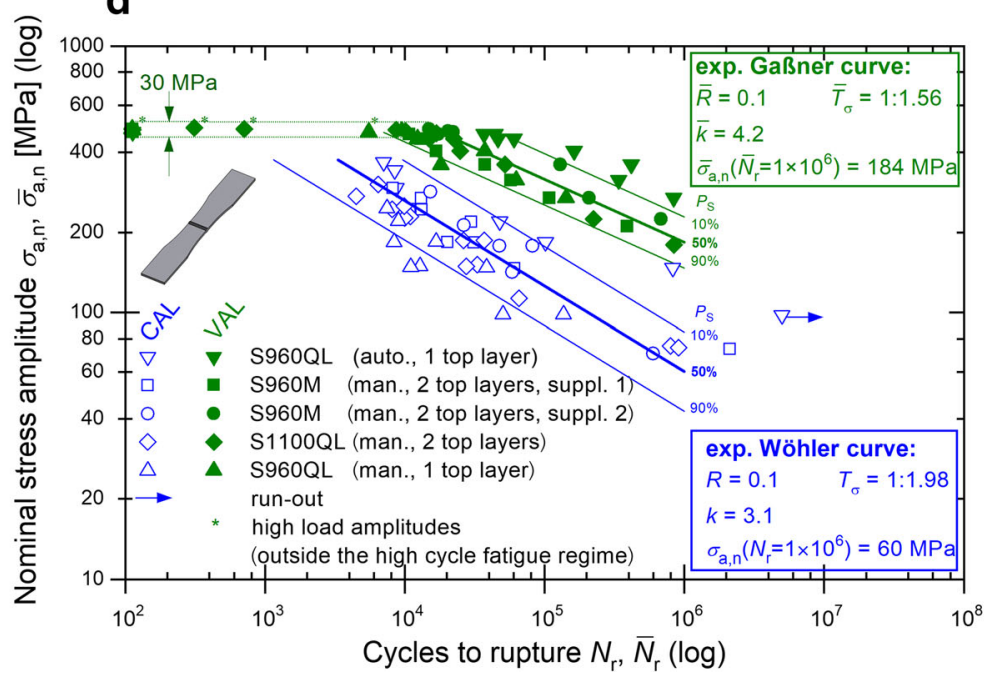

Fig. 3 a Fatigue test setup. b Load time history. c Load spectrum. d Fatigue test results

weld, this extensometer contains the entire weld area (weld metal, HAZ, and base metal on both sides).

Two approaches are used to evaluate the strain-life curve: the classical description of the Basquin-Coffin-MansonMorrow (BCMM) [38-41] strain-life curve and the description by the tri-linear strain-life curve [42]. In the latter description, continuation of the slope of the elastic line from range 2 into $3\left(b_{2}=b_{3}\right)$ is selected, since no results are available for $N>1 \cdot 10^{6}$. The comparison of the BCMM strain-life curves with the tri-linear strain-life curves for the S1100QL butt welds (Fig. 6a) shows differences between the two estimation methods - with a more accurate description by the tri-linear strain-life curve and cyclic stress-strain curve derived from compatibility equations. Therefore, the tri-linear strain-life curve is preferred in describing the strain-life relation and will be used to estimate the fatigue life. There are approx. 1-2 decades in number of cycles to crack initiation between the base material and butt weld. In [19], it has also been demonstrated that a fatigue life reduction has been found for machined specimens compared with the base material state. Thus, it can be seen that the strain-life curves determined on base material specimens cannot be directly transferred to other material states, such as weld seams.

Cyclic stress-strain curves are described according to Ramberg-Osgood [43]. In addition to the direct regression of the test results, cyclic stress-strain curves have been derived 
Fig. 4 Schematic presentation of the integral treatment of butt joints and resulting stress-strain states under strain-controlled fatigue testing

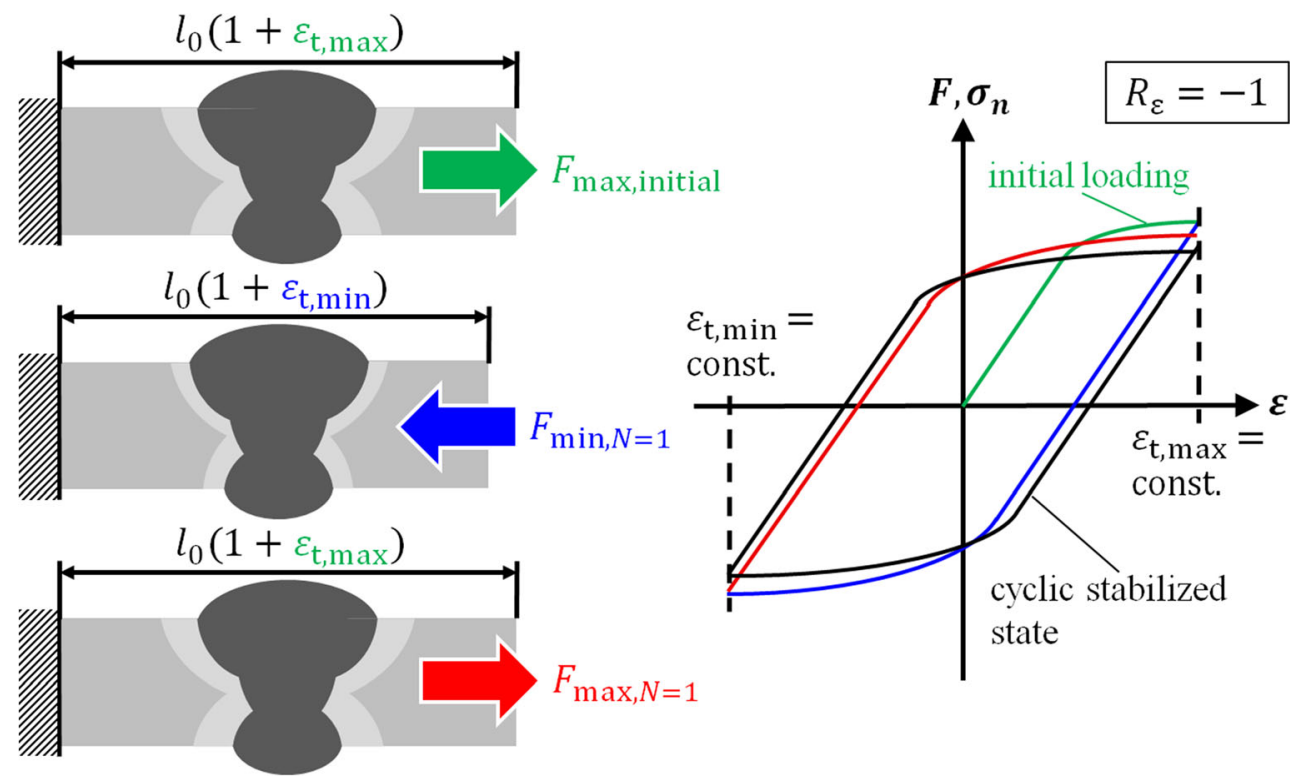

from compatibility with the strain-life curve in the form of BCMM and the tri-linear strain-life curve. The three descriptions are compared for the S1100QL butt welds in Fig. 6b. The stress-strain curves from the compatibility with the BCMM strain-life curves tend to underestimate the results for lower plastic strains $\left(0.2 \%<\varepsilon_{\mathrm{a}, \mathrm{t}}<0.5 \%\right)$ and to overestimate the results for large plastic strains $\left(\varepsilon_{\mathrm{a}, \mathrm{t}}>0.6 \%\right)$. In contrast, the direct regression and the cyclic stress-strain curve describe the tri-linear strain-life curve more accurately. This also applies in a similar way for the curves of the other base materials. All evaluated cyclic stress-strain curves are based on the results for the cyclically stabilized state and thus do not reflect any transient effects. Cyclic material parameters of the investigated high-strength, fine-grained steels and butt-welded joints have been documented and analyzed in more detail in $[2,19]$.

\subsection{Cyclic transient behavior}

A first impression regarding transient effects is given by a comparison of the initial loading with the cyclic stabilized state and, especially the cyclic stress-strain curve. Distinctive cyclic softening from initial loading to cyclic stabilization can be observed for high-strength steel base materials as well as butt joints (cf. Fig. 4 (right)). However, deeper insight into the cyclic transient behavior is gained from changes in the hysteresis loops from cycle to cycle. The transient behavior is shown more clearly in the evolution of the cyclic yield strength $R_{p 0.2}$ or the cyclic hardening coefficient $\mathrm{K}^{\prime}$ and the cyclic hardening exponent $\mathrm{n}^{\prime}$. An overview is provided by the representation of $\mathrm{K}^{\prime}$ and $\mathrm{n}^{\prime}$ in relation to the normalized number of cycles to crack initiation $\mathrm{N} / \mathrm{N}_{\mathrm{i}}$ for $\mathrm{S} 960 \mathrm{QL}$ in Fig. 7, from which a drop in the cyclic hardening coefficient $\mathrm{K}^{\prime}$ can be derived as a result of softening and crack initiation. The cyclic hardening exponent $\mathrm{n}^{\prime}$ also shows a decreasing trend, although for S960QL steel and butt welds, it remains almost constant with increasing $\mathrm{N} / \mathrm{N}_{\mathrm{i}}$, apart from a few minor changes. For both cyclic parameters, a linearization is performed for continuous evolution, so that (linear) functional relations for $\mathrm{K}^{\prime}=f\left(\mathrm{~N} / \mathrm{N}_{\mathrm{i}}\right)$ and $\mathrm{n}^{\prime}=f\left(\mathrm{~N} / \mathrm{N}_{\mathrm{i}}\right)$ are found. Due to the change in the characteristic values resulting from cyclic softening and crack initiation, the

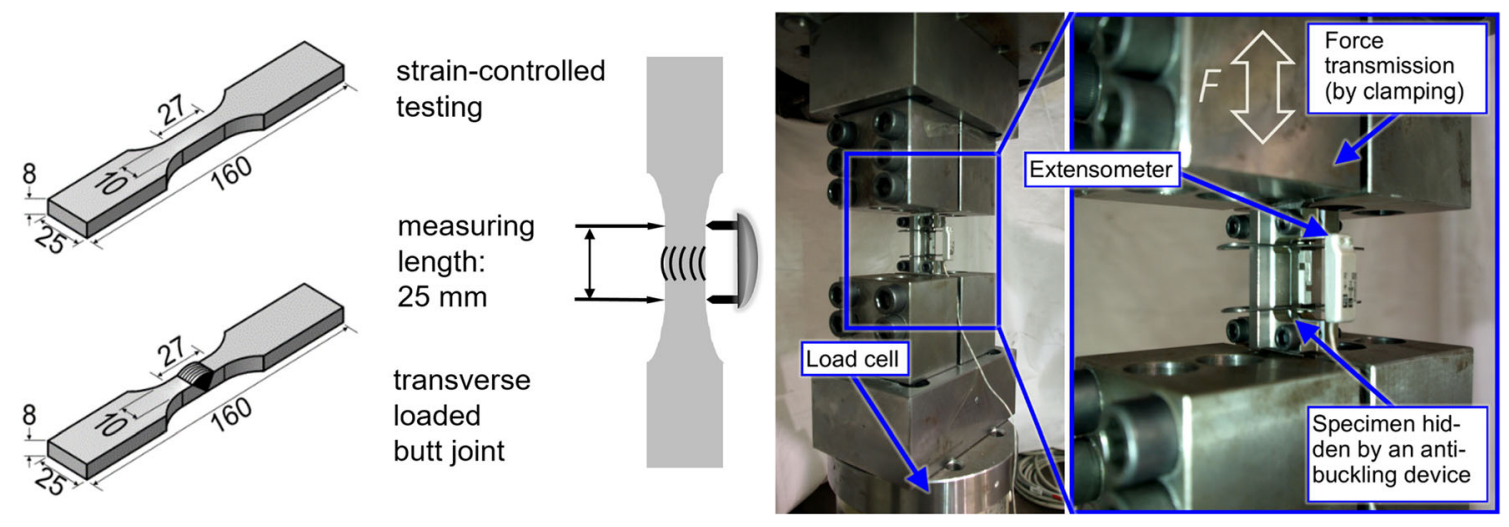

Fig. 5 Strain-controlled fatigue testing and investigated flat specimen geometries 

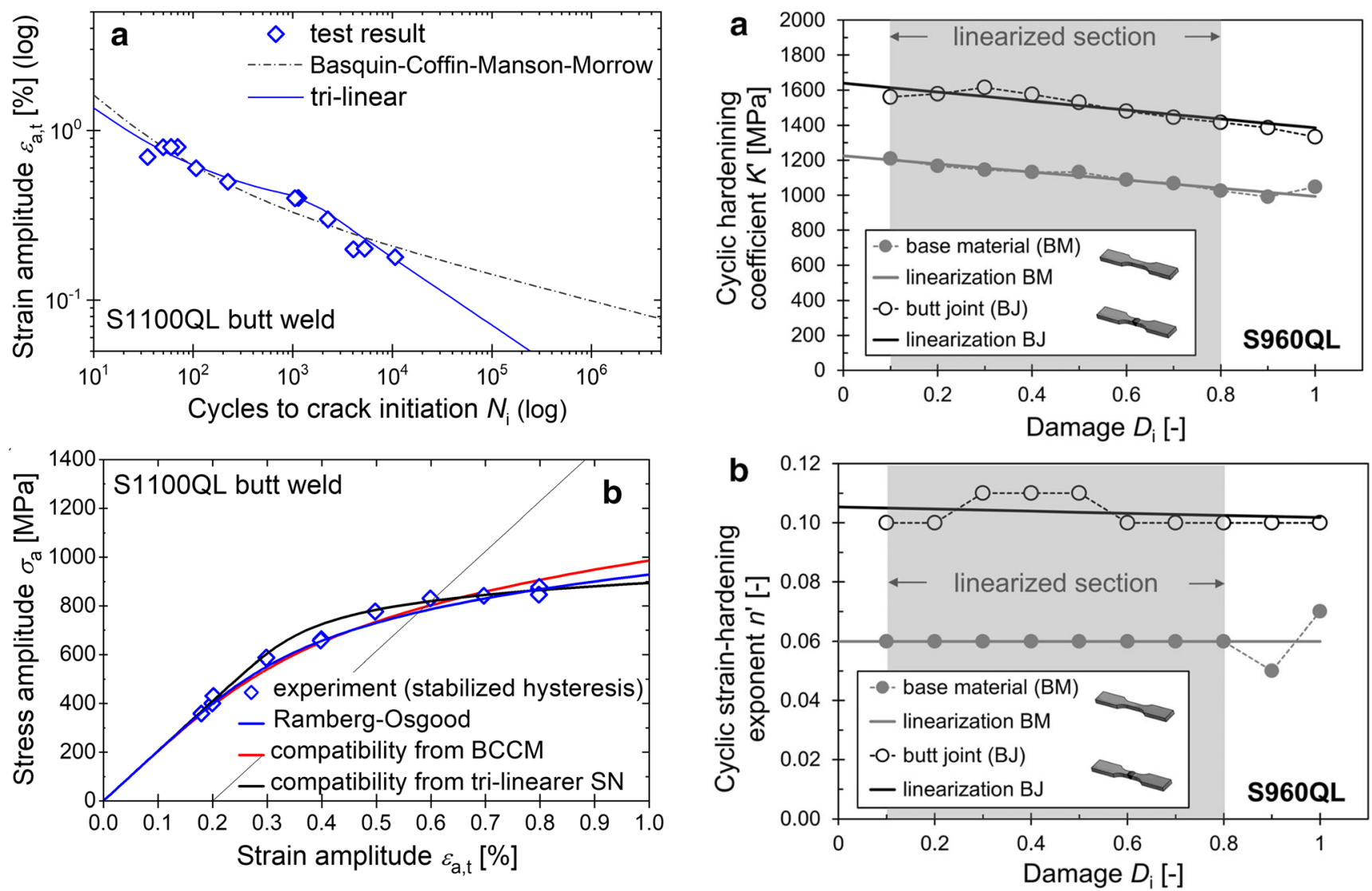

Fig. 6 Comparison of the BCMM evaluation and tri-linear approach of S1100QL butt welds for a strain-life curves and $\mathbf{b}$ cyclic stress-strain curves

normalized number of cycles from strain-controlled fatigue tests can be directly interpreted as total damage, so that $\mathrm{D}=$ $\mathrm{N} / \mathrm{N}_{\mathrm{i}}$ follows. This definition results in the linearized descriptions for $\mathrm{K}^{\prime}$ and $\mathrm{n}^{\prime}$ depending on the damage according to Eqs. 1 and 2, where the index " 0 " denotes the initial state. More complex, non-linear relationships are also conceivable, but for the following investigation, this approximation is sufficient for the description of the cyclic transient behavior.

$$
\begin{aligned}
& K_{j}^{\prime}\left(D_{j}\right)=\Delta K^{\prime} \cdot D_{j}+K_{0}^{\prime} \\
& \mathrm{n}_{j}^{\prime}\left(D_{j}\right)=\Delta n^{\prime} \cdot D_{j}+n_{0}^{\prime}
\end{aligned}
$$

\section{Fatigue life estimation approach}

For the fatigue life estimation from the low cycle to the high cycle fatigue regime, a strain-based approach, using damage parameters to assess simulated stress-strain paths, is used. The approach is based on the integral treatment of the butt weld already examined and its characterization by the cyclic (transient) behavior (Fig. 8). This approach includes the following steps:

Fig. 7 Description of the cyclic transient behavior by (linear) functional relations between Ramberg-Osgood parameters and total damage for a the cyclic hardening coefficient $\mathrm{K}^{\prime}$ and $\mathbf{b}$ the cyclic hardening exponent $\mathrm{n}^{\prime}$

1. The starting points of the evaluation are the butt-welded specimens described before, which provide "integral characteristic values of the cyclic behavior of transverse loaded butt joints" as a result of strain-controlled fatigue tests. For the initial loading, stress-strain curves based on the initial parameters $\mathrm{K}_{0}^{\prime}$ and $\mathrm{n}_{0}^{\prime}$ are applied. Likewise, additional stresses (and strains) resulting from an angular misalignment are applied in the first load step.

2. In the second step, the cyclic transient behavior of these "integral weld seams" is directly used in the analytical simulation of stress-strain paths, considering memory and Masing behavior without explicitly determining a fictitious notch stress or strain. Hysteresis loops are related to the load history. Different loading histories therefore need to be simulated computationally with this procedure. According to the force-controlled tests of the butt welds with $\mathrm{R}_{\mathrm{F}}=0$, constant and variable amplitude loading is simulated in order to verify this method. The application of this method allows the inclusion of transient effects, such as cyclic softening, in the fatigue assessment with moderate effort. Based on the description of the cyclic transient behavior, the first load with stress relief is calculated using $\mathrm{K}_{0}{ }^{\prime}$ and $\mathrm{n}_{0}{ }^{\prime}$ from the initial Ramberg-Osgood 


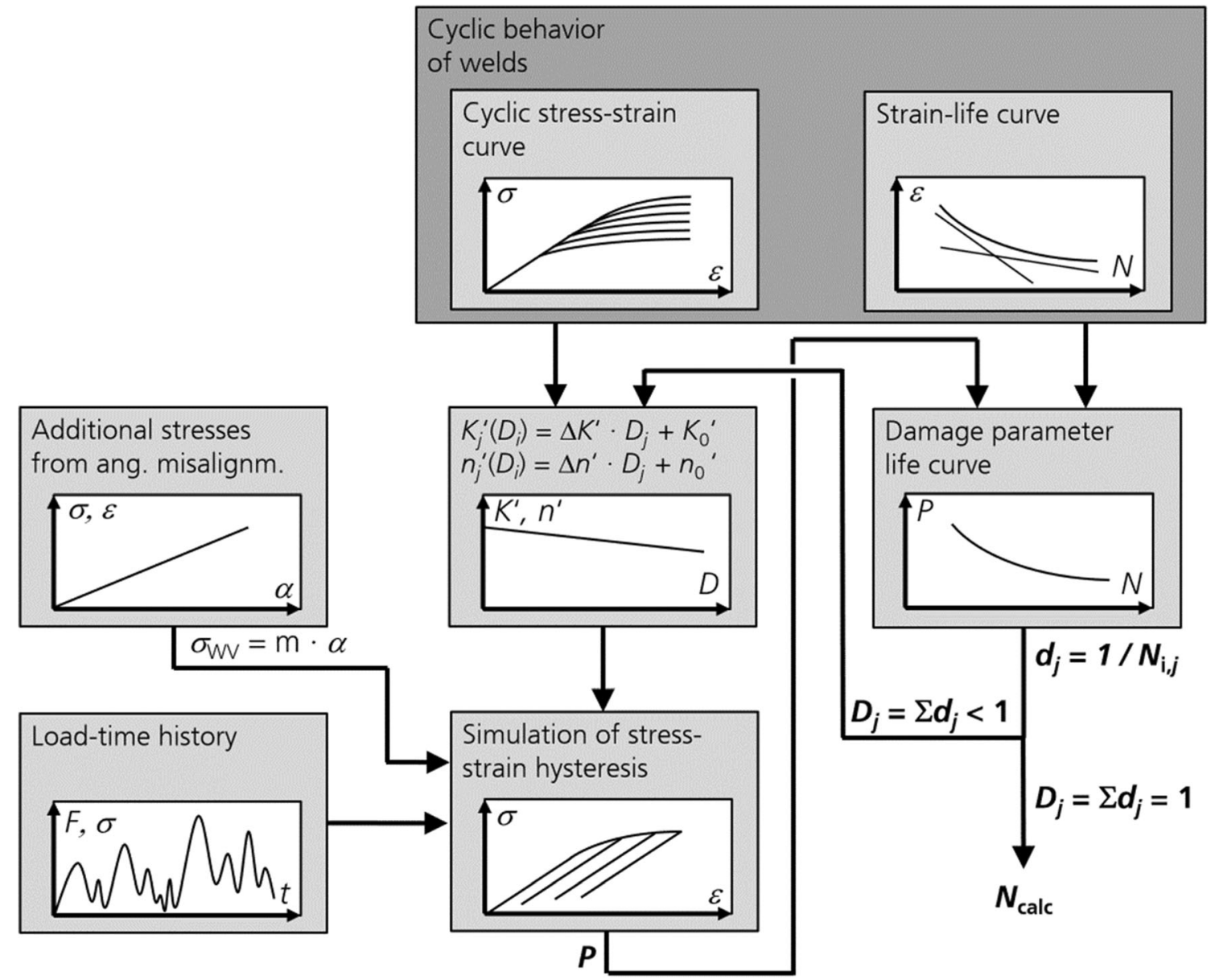

Fig. 8 Overview of the fatigue life estimation procedure for butt welds using cyclic transient behavior

equation, while the following stress hystereses are calculated by damage-dependent linearized parameters of $\mathrm{K}^{\prime}$ and $\mathrm{n}^{\prime}$. The Ramberg-Osgood parameters $\mathrm{K}^{\prime}$ and $\mathrm{n}^{\prime}$ are modified cycle by cycle on the basis of the functional relationship with the damage content.

3. The damage of every resulting hysteresis is derived by common damage parameters $\mathrm{P}_{\mathrm{SWT}}$ by Smith-Watson-Topper [44] (Eq. 3), $\mathrm{P}_{\varepsilon}$ by Sonsino-Werner [45, 46] (Eq. 4), modified $\mathrm{P}_{\mathrm{HL} \text {,mod }}$ by Haibach-Lehrke [47] (Eq. 5), and $\mathrm{P}_{\mathrm{J}}$ by Vormwald [48] or the evolved $\mathrm{P}_{\mathrm{RAJ}}$ by Fiedler et al. [49] (Eq. 6), which are finally compared. As a result of the analysis of these damage parameters, a generalized damage parameter $\mathrm{P}_{\mathrm{m}}$ (Eq. 7) is introduced, which includes additional factors for mean stresses and mean strains as a combination of $\mathrm{P}_{\varepsilon}$ and the damage parameter of Bergmann $\mathrm{P}_{\mathrm{B}}[50]$.

$$
\begin{aligned}
& P_{\text {SWT }}=\sqrt{\sigma_{\max } \varepsilon_{a} E}=\sqrt{\left(\sigma_{\mathrm{a}}+\sigma_{\mathrm{m}}\right) \varepsilon_{\mathrm{a}} E} \\
& P_{\varepsilon}=\sqrt{\varepsilon_{\max } \sigma_{\mathrm{a}} E}=\sqrt{\left(\varepsilon_{\mathrm{a}}+\varepsilon_{\mathrm{m}}\right) \sigma_{\mathrm{a}} E} \quad b z w . \\
& P_{\varepsilon}=\sqrt{\left(\varepsilon_{\mathrm{a}}+k \varepsilon_{\mathrm{m}}\right) \sigma_{\mathrm{a}} E}
\end{aligned}
$$

4. With the help of the relation between damage parameter $\mathrm{P}$ and cycles to crack initiation $\mathrm{Ni}$, the partial damage of the $j$ th cycle $d_{j}$ is derived and added to the damage sum of previous cycles. The accumulation is ongoing as long as the damage sum is below the theoretical damage sum of $\mathrm{D}_{\mathrm{th}}=1$.

5. The failure in the form of the crack initiation from the strain-controlled testing is achieved and the calculated number of cycles $\mathrm{N}_{\text {calc }}$ is returned, when the theoretical damage sum of $\mathrm{D}_{\mathrm{th}}=1$ is reached.

A comparison between experimentally derived and simulated stress-strain paths, for a constant amplitude stresscontrolled loading situation with $\mathrm{R}_{\mathrm{F}}=-1$ until the theoretical damage sum of $D_{\text {th }}=1$ is reached, is shown in Fig. 9. Experimentally derived, simulated stress-strain paths and 
resulting hysteresis loops are in good agreement. Smaller differences occur at the minimum stress under compression, where cyclic creep might have an influence on the turning point. However, fatigue lives have been calculated by application of introduced damage parameters. Except for a short

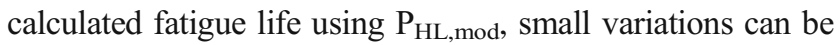
found for most of the damage parameters and in comparison with the experimentally determined value, in this specific example. In any case, the previously defined $\mathrm{P}_{\mathrm{m}}$ seems to be a good choice. In other loading situations, advantages and disadvantages become clearer, as can be seen from [2].

This procedure offers the advantage of a simplified fatigue life estimation, based on consideration of elastic-plastic stresses. Using this approach, a detailed and complex finite element simulation for the assessment of notch stresses or strains, which should additionally take transient effects into account, is avoided.

\section{Fatigue life estimation}

\subsection{Constant amplitude loading (CAL)}

According to the procedure described before, a fatigue life estimation under constant amplitude loading for the integral treatment of butt welds considering the cyclic transient behavior using damage parameters as defined in Eqs. 3 to 7 has been performed, where $\mathrm{P}_{\mathrm{m}}$ is the introduced generalized damage parameter including mean stresses and mean strains. The results, applying the damage parameter $\mathrm{P}_{\mathrm{m}}$, are presented in Fig. 10, since $\mathrm{P}_{\mathrm{m}}$ can be adjusted to the LCF regime (mean strains) and HCF regime (mean stresses) by choice of the corresponding factors in addition to the consideration of stress and strain amplitudes. In the nominal stress system, fatigue lives estimated with the help of $\mathrm{P}_{\mathrm{m}}$ are compared with experimentally derived cycles to failure and fatigue classes FAT 50/ 71 (dot-dash-lines corresponding to a survival probability of $P_{S}=97.7 \%$ ) derived for the different test series, which are characterized by the combination of base material and welding process execution. Figure 10a shows that the estimation results in too long fatigue lives for S960QL butt welds (green triangles), where specimens include a comparably high angular misalignment of $\alpha=3.9^{\circ}$ on average, if this angular misalignment is not taken into account in the fatigue life simulation(gray curve for $\mathrm{P}_{\mathrm{S}}=50 \%$ ). Including an average angular misalignment $\alpha=3.9^{\circ}$ in the estimation procedure, it can be seen, from the course of the estimated fatigue life curve (cf. black curve) corresponding to a survival probability of $\mathrm{P}_{\mathrm{S}}=50 \%$, that the accuracy of the fatigue life estimation is increased. Therefore, calculated fatigue lives of the other test series in Fig. 10b, c, and d already include the angular misalignment (black curves for $\mathrm{P}_{\mathrm{S}}=50 \%$ ). It can be seen that the estimated fatigue lives coincide very well with the loadcontrolled experimental results for S960QL (Fig. 10a) and S1100QL (Fig. 10b), while more conservative fatigue lives are found for S960M (supplier 2, Fig. 10d). S960M (supplier 1) shows a good agreement at higher load levels and tends to be non-conservative at lower load amplitudes (Fig. 10c).
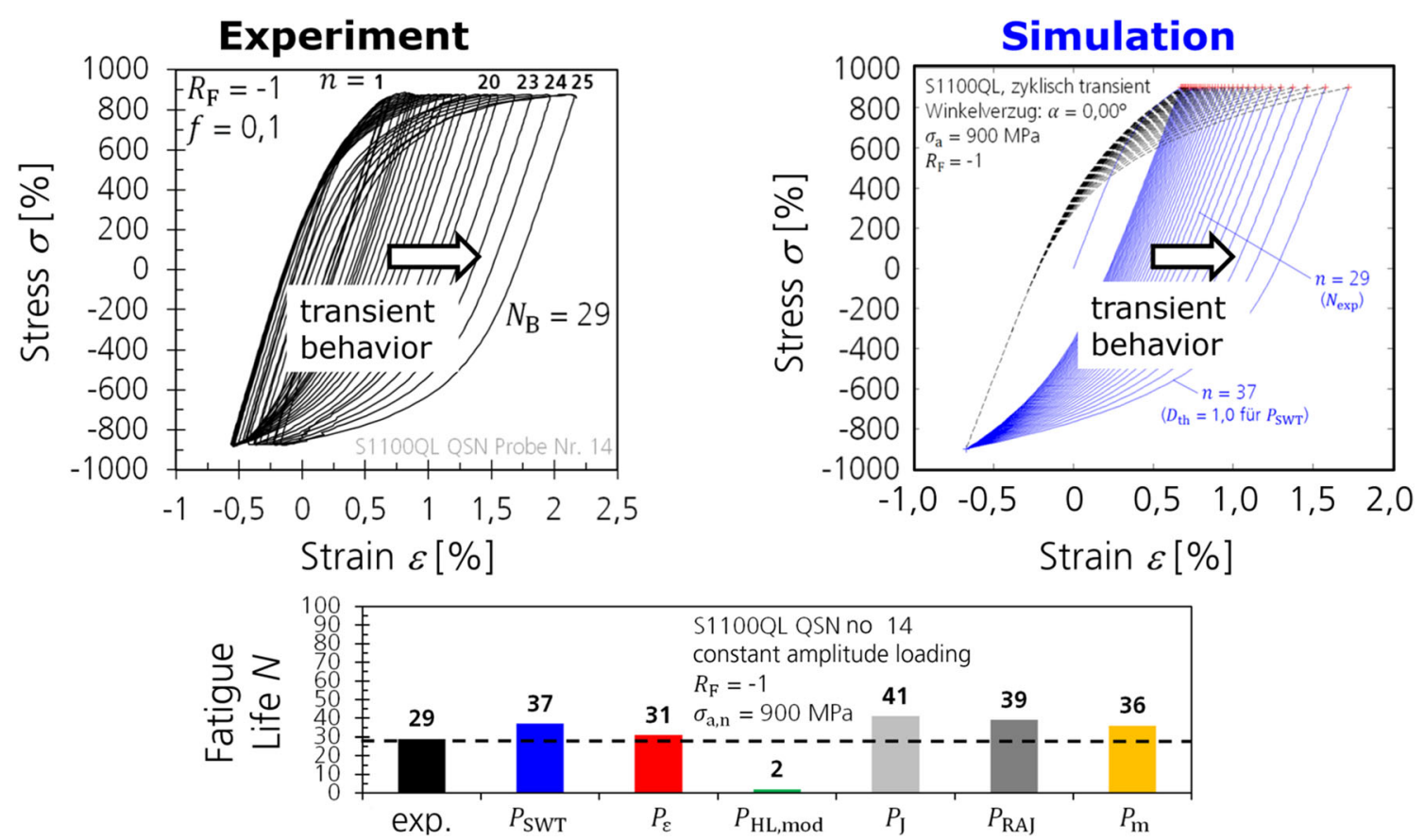

Fig. 9 Comparison between experimentally derived and simulated stress-strain paths for a constant amplitude stress-controlled loading situation with $\mathrm{R}_{\mathrm{F}}=-1$ as well as estimated fatigue lives depending on the choice of damage parameter 

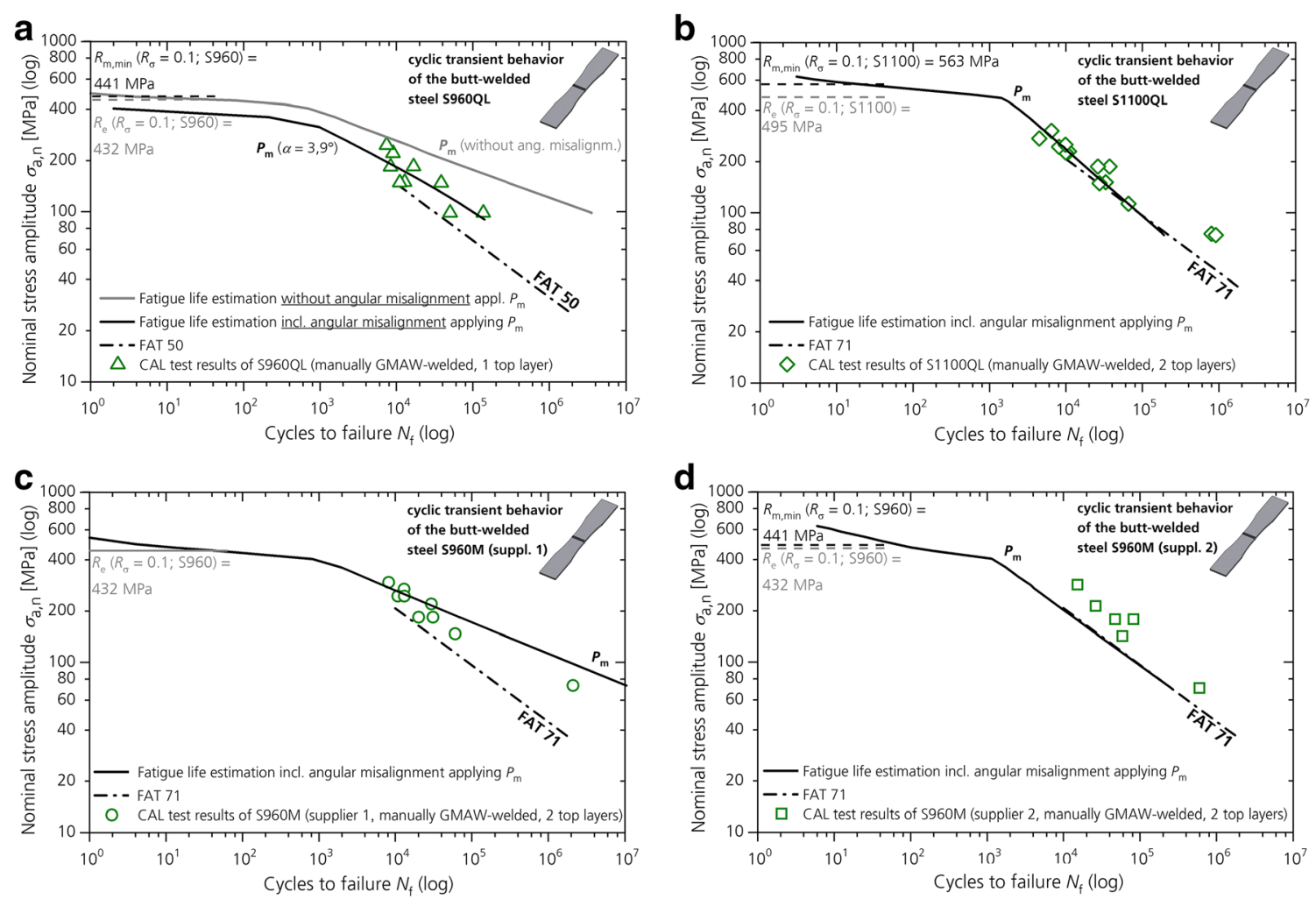

Fig. 10 Fatigue life estimation under constant amplitude loading applying the damage parameter $\mathrm{P}_{\mathrm{m}}$ compared with fatigue classes (FAT) based on the cyclic transient behavior of the butt-welded steels a S960QL, b S1100QL, c S960M (supplier 1) and d S960M (supplier 2)

\subsection{Variable amplitude loading (VAL)}

Under variable amplitude loading, the simulated stress-strain path is more complex than the one for constant amplitude loading. Again, the fatigue life estimation is carried out for the integral treatment of butt welds with the described procedure considering cyclic transient behavior. Due to the intersection of the black curves for $\mathrm{P}_{\mathrm{S}}=50 \%$ with the green symbols, Fig. 11a, $\mathrm{b}$, and $\mathrm{c}$ show that the highest stress amplitudes of loadcontrolled tests have been assessed by the approach applying the damage parameter $\mathrm{P}_{\mathrm{m}}$. For manually welded butt joints made of S960M (supplier 1, cf. Fig. 11c), there is a very good agreement between estimated and experimentally determined fatigue lives under variable amplitude loading. In the other cases, S960QL (Fig. 11a), S1100QL (Fig. 11b), and S960M (supplier 2, Fig. 11d), there is a tendency to be more conservative, when the stress amplitude decreases. Compared with the linear damage accumulation for $\mathrm{P}_{\mathrm{S}}=50 \%$ (here: using the allowable damage sum acc. to [5] of $\mathrm{D}_{\text {all }}=0.5$ ), this approach is not based on Wöhler (SN) lines derived under constant amplitude loading and is therefore independent of the slope of the Wöhler line in the HCF regime. As can be seen from Fig. 11, the transition from low cycle to high cycle fatigue is represented in a good way using this method, so that the calculated Gaßner (or Wöhler) curve is not purely linear (in double-logarithmic scale). However, in the HCF regime, the approximation of a straight line for the Gaßner curve becomes obvious and is reasonable. At lower load levels, the estimation from the integral treatment of butt joints shows a good agreement for S960QL (cf. Fig. 11a) and S960M (supplier 1, cf. Fig. 11c), while the linear damage accumulation is closer to the experimental data for S1100QL (Fig. 11b) and S960M (supplier 2, Fig. 11d).

\section{Discussion of the fatigue life estimation}

Estimated (calculated) fatigue lives $\mathrm{N}_{\text {calc }}$ for the integral treatment of butt welds, considering the cyclic transient behavior using damage parameter $\mathrm{P}_{\mathrm{m}}$, are directly compared with experimentally derived fatigue lives $\mathrm{N}_{\text {exp }}$ for both constant and variable amplitude loading. Resulting data in the range of 1:4 from the optimum $\mathrm{N}_{\text {calc }}=\mathrm{N}_{\text {exp }}$ (factor of 4) show a good agreement within the overall scatter of welded joints. In the case where $\mathrm{N}_{\text {calc }}$ is larger by more than a factor of 4 compared with $\mathrm{N}_{\text {exp }}$, the estimation is on the unsafe side, while it is defined to be too safe, if $\mathrm{N}_{\text {calc }}=0.25 \cdot \mathrm{N}_{\text {exp }}$.

In Fig. 12, the direct comparison between calculated and experimentally determined fatigue lives for constant amplitude loading, applying the damage parameter $\mathrm{P}_{\mathrm{m}}$, confirms the good agreement which Fig. 10 indicates, if the angular distortion is taken into account-apart from the still very conservative estimate for the S960M (supplier 2). It can be seen that most results for S960QL (cf. Fig. 10a), S1100QL (cf. 

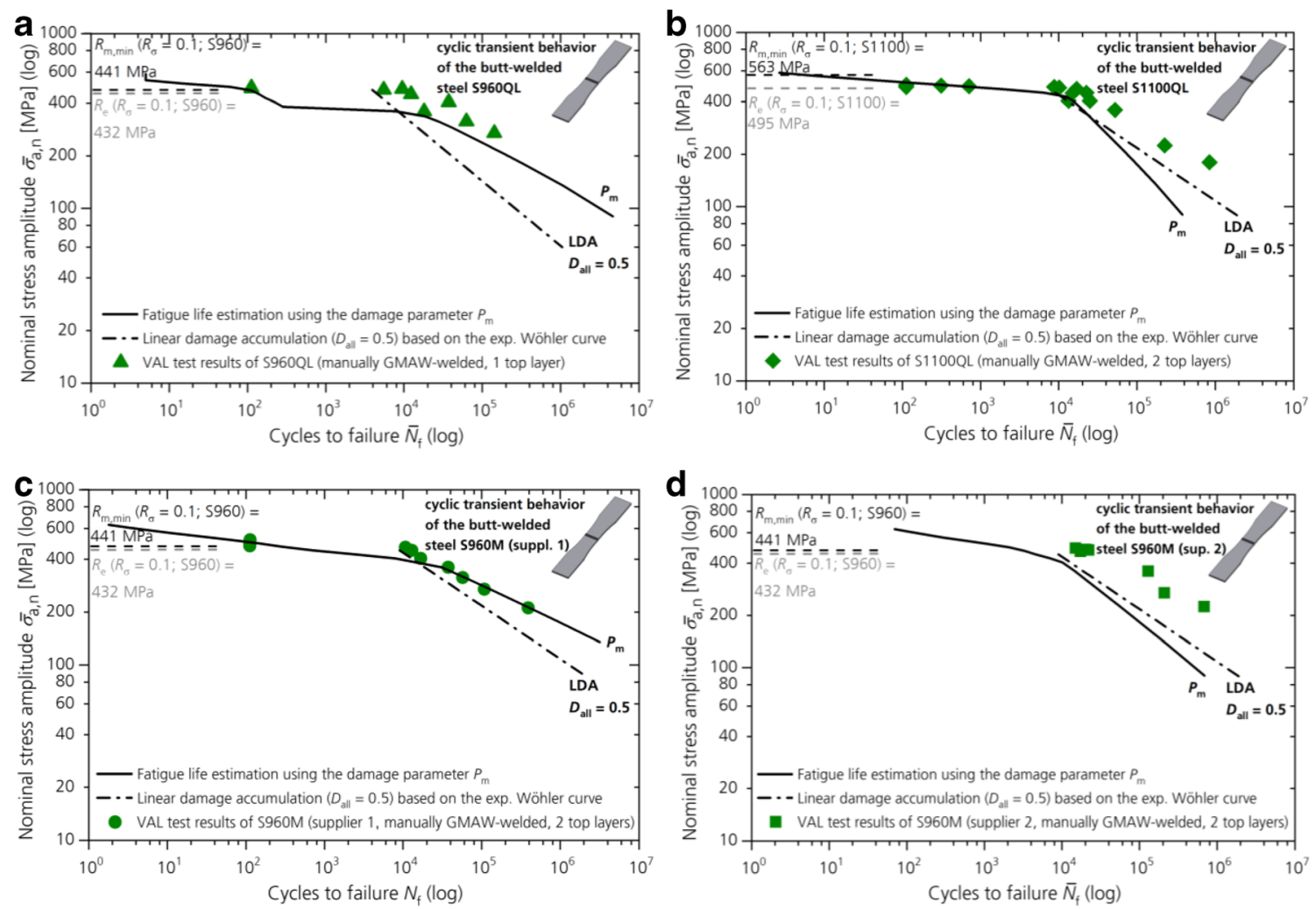

Fig. 11 Fatigue life estimation under variable amplitude loading using the damage parameter $\mathrm{P}_{\mathrm{m}}$ compared with the linear damage accumulation with $\mathrm{D}_{\mathrm{all}}=0.5$ based on the cyclic transient behavior of the butt-welded steels a S960QL, b S1100QL, c S960M (supplier 1) and d S960M (supplier 2)

Fig. 10b), and S960M (supplier 1, Fig. 10c) are in the 1:4 range. In addition to the results of S960M (supplier 2), some of the other results at lower load amplitudes tend to be too safe. However, test results at low load levels are rare, since the focus of this investigation is set on the regime from LCF to higher load levels of the HCF. Therefore, the significance of the fatigue life estimation for very low load levels is limited, based on the results of this investigation. On the other hand, a

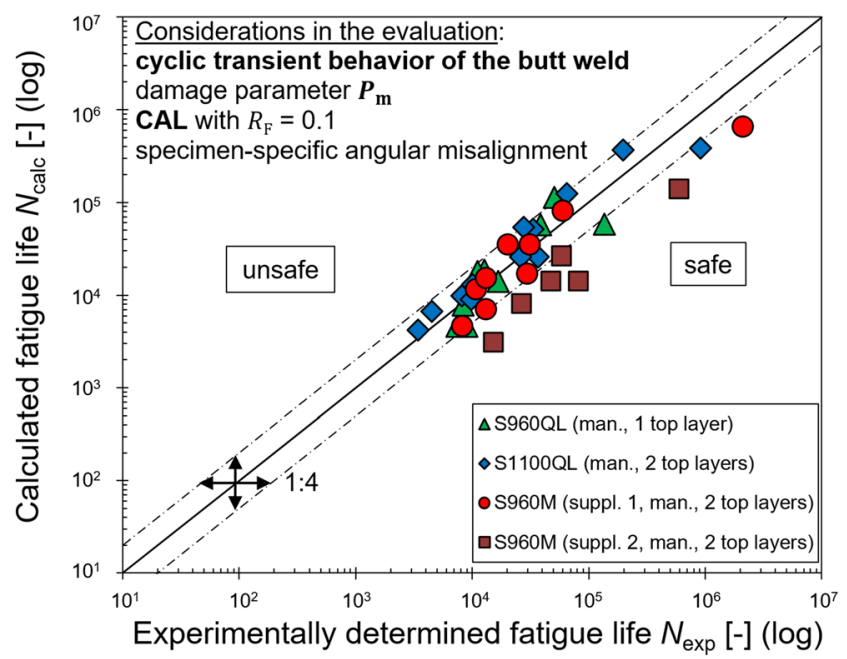

Fig. 12 Comparison between calculated and experimentally determined fatigue lives for constant amplitude loading applying the damage parameter $\mathrm{P}_{\mathrm{m}}$ very good agreement between estimated and experimentally derived fatigue lives at high load levels is found, at least for S960QL, S1100QL, and S960M (supplier 1) butt welds.

Figure 13 shows the comparison between calculated and experimentally determined fatigue lives for variable amplitude loading, applying the damage parameter $\mathrm{P}_{\mathrm{m}}$, again taking the angular distortion into account. For VAL, the estimation is less accurate than for CAL and leads to some results on the

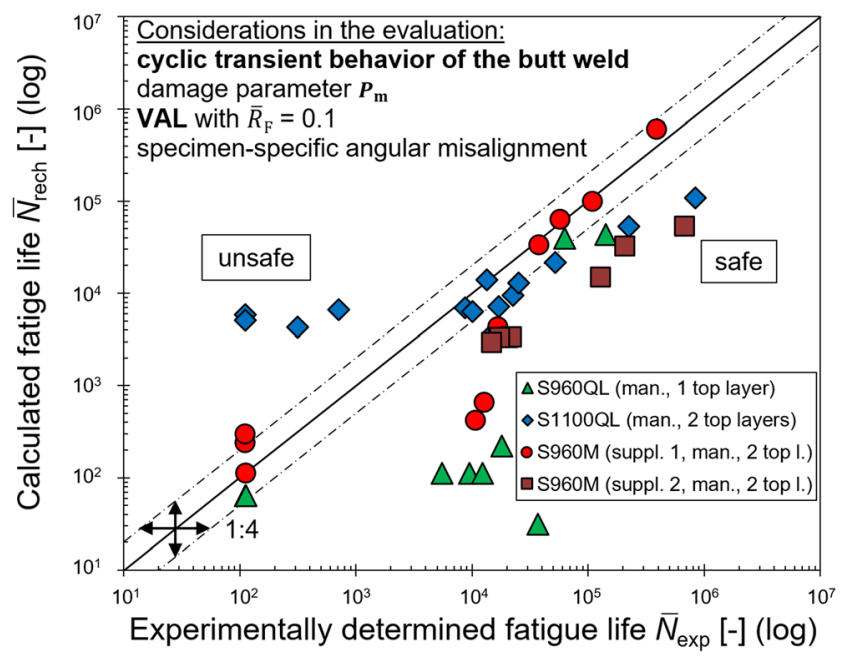

Fig. 13 Comparison between calculated and experimentally determined fatigue lives for variable amplitude loading applying the damage parameter $\mathrm{P}_{\mathrm{m}}$ 
unsafe side — at least in a few cases of high loads for S1100QL and one result for S960M (supplier 1). For many results in the LCF regime, when elastic-plastic behavior and mean strains come into play, but also at low stress amplitudes of the HCF regime, where linear-elastic behavior can be assumed, the experimentally determined fatigue lives exceed the calculated ones, which gives a conservative estimation beyond the factor of 4. However, again, the same applies as for low load levels from constant amplitude loading: the significance of the estimation is low due to few test results in this regime.

Based on the integral treatment of butt welds, the cyclic behavior of the seam weld is determined and successfully used for a fatigue life estimation of corresponding joints under CAL and VAL. The estimation for CAL is in good agreement with the experiment showing some results that are too safe, while the VAL estimation tends to be very conservative, but still having some unsafe results. In both cases, consideration of the transient behavior for the fatigue life estimation is beneficial, especially at high load levels at the border to the LCF regime. The conservative estimations in the LCF regime using this method is still superior compared with the linear damage accumulation, which just gives a constant slope of the calculated Gaßner line depending on the slope of the Wöhler curve. A limitation in the LCF regime can then just be constituted by knowledge about the yield or tensile strength of the joint. Therefore, further work on this approach is expedient, in order to improve the fatigue life estimation in the regime from HCF to LCF.

\section{Conclusions}

A method for fatigue life estimation based on an integral treatment of transversely loaded butt joints has been introduced. The following conclusions can be drawn from this investigation and the developed fatigue life estimation using an integral treatment of welds:

(a) A description of the substructure from base material to base material by its cyclic behavior (integral treatment) is the basis. The characterization by an accumulated set of parameters results in a unification and simplification, compared with locally detailed modeling of the weld. As might be seen from the hardness distribution of a section cut from the weld seam, huge variations in micro-hardness from one measurement point to another exist (cf. [2, 51, 52]). By implementation of a distribution of local characterization parameters in local fatigue concepts by FE modeling and simulation, calculation time increases drastically.

(b) For the assessment from the low cycle to the high cycle fatigue regime, the cyclic elastic-plastic behavior was considered. The cyclic transient behavior shows a distinctive cyclic softening of the base materials and butt welds, which is described by a damage-dependent definition of the cyclic characteristic values $\mathrm{K}^{\prime}$ and $\mathrm{n}^{\prime}$ of the Ramberg-Osgood equation. This is the main proposal to describe transient effects within this approach. Other transient effects, mean stress relaxation and cyclic creep, were not explicitly considered. In particular, cyclic creep requires further strain-rate-dependent investigations.

(c) Additional influences on the fatigue performance result from global geometrical factors, such as axial and angular misalignments. Axial misalignments are small and can be neglected. The angular distortion depends on the execution of the weld with respect to the boundary conditions. Furthermore, the heat input of the welding process influences the angular misalignment or residual stresses for fixed connections to the entire structure. While LBW creates a smaller angular misalignment, the increased heat input of GMAW induces a larger distortion. Therefore, the angular misalignment is considered with the help of additional stresses (and strains), which improves the fatigue life estimation.

(d) The choice of damage parameter $-\mathrm{P}_{\mathrm{SWT}}, \mathrm{P}_{\varepsilon}, \mathrm{P}_{\mathrm{HL}, \bmod }, \mathrm{P}_{\mathrm{J}}$, and $\mathrm{P}_{\mathrm{RAJ}}$ were evaluated - influences the fatigue life estimation. Finally, a generalized damage parameter $\mathrm{P}_{\mathrm{m}}$ (combination of $\mathrm{P}_{\mathrm{B}}$ and $\mathrm{P}_{\varepsilon}$ ) has been introduced, which can be adjusted to the regime, where damage is dominated by mean stresses (HCF) or mean strains (LCF) in addition to stress and strain amplitudes. This has been achieved by additional factors for the mean stress and mean strain in the mathematical formulation.

(e) The application of the integral life estimation method has been illustrated by lifetime estimations for constant and variable amplitude loading. It has been found that the estimation is in good agreement with experimental stresscontrolled results under constant amplitude loading, while the estimated life under variable amplitude loading tends to be on the safe side for lower loading situations. In general, the (double-logarithmic) non-linear transition from LCF to HCF can be estimated with this method.

Acknowledgments Open Access funding enabled and organized by Projekt DEAL. The basis for this work was established during my time as a research assistant at the Research Group System Reliability, Adaptive Structures, and Machine Acoustics of the Technische Universität Darmstadt and the Fraunhofer LBF. For their support, the author would like to thank Prof. C.M. Sonsino, Prof. T. Melz, Prof. M. Vormwald, Dr.Ing. H. Kaufmann, Dr.-Ing. R. Wagener, and the colleagues at the corresponding institutes. The related research projects "Enhancement of the Local Concept of Fatigue Assessment of Welded Crane Structures of High Strength Steels in the Low Cycle Fatigue Regime", IGF-projectno. $17102 \mathrm{~N}$, and "Fatigue Life Assessment of Laser Beam and Laser Hybrid Welded Crane Structures made of High-Strength Steels“, IGFproject-no. 19272 N, of the Research Association for Steel Application (FOSTA-Forschungsvereinigung Stahlanwendung e.V.) are funded by the AiF as part of the program for »Joint Industrial Research (IGF)« by the German Federal Ministry of Economic Affairs and Energy (BMWi) by decision of the German Bundestag. 
Open Access This article is licensed under a Creative Commons Attribution 4.0 International License, which permits use, sharing, adaptation, distribution and reproduction in any medium or format, as long as you give appropriate credit to the original author(s) and the source, provide a link to the Creative Commons licence, and indicate if changes were made. The images or other third party material in this article are included in the article's Creative Commons licence, unless indicated otherwise in a credit line to the material. If material is not included in the article's Creative Commons licence and your intended use is not permitted by statutory regulation or exceeds the permitted use, you will need to obtain permission directly from the copyright holder. To view a copy of this licence, visit http://creativecommons.org/licenses/by/4.0/.

\section{References}

1. Kirschbaum M, Hamme U (2015) Einsatz von hochfesten Feinkornbaustählen im Kranbau. Stahl und Eisen 135(5):69-74

2. Möller B (2020) Integrale Betrachtung zur Lebensdauerabschätzung von Stumpfnähten im Bereich der Kurzzeitschwingfestigkeit. Dissertation, Technische Universität Darmstadt, Technical report FB-257, Fraunhofer Verlag, Stuttgart

3. DIN EN 1993-1-9 (2010) Eurocode 3: design of steel structures part 1-9: fatigue; German version EN 1993-1-9:2005 + AC:2009. Beuth Verlag GmbH, Brüssel

4. DIN EN 13001-3-1 (2019) cranes - general design - part 3-1: limit states and proof competence of steel structure; German version EN 13001-3-1:2012+A2:2018. Beuth Verlag GmbH, Berlin

5. Hobbacher AF (2016) Recommendations for fatigue design of welded joints and components. IIW document IIW-2259-15 ex XIII-2460-13/XV-1440-13, Second Edition, International Institute of Welding, Springer-Verlag, Berlin/Heidelberg. ISBN 978-3319-23756-5

6. Rennert R, Kullig E, Vormwald M, Esderts A, Siegele D (2012) FKM Richtlinie - Rechnerischer Festigkeitsnachweis für Maschinenbauteile aus Stahl, Eisenguss- und Aluminiumwerkstoffen. 6th revised edition; Editor: Forschungskuratorium Maschinenbau (FKM), Frankfurt / Main

7. Sonsino CM Concepts and required materials data for fatigue design of PM components. Conference proceedings of the European Congress and Exhibition on Powder Metallurgy (PM 2001), 22-24 Oct 2001, Nice, p 80-109s

8. Radaj D, Sonsino CM, Fricke W (2006) Fatigue assessment of welded joints by local approaches, 2 nd edn. Woodhead Publishing, Cambridge

9. Radaj D, Sonsino CM, Fricke W (2009) Recent developments in local concepts of fatigue assessment of welded joints. International Journal of Fatigue 31:2-11. https://doi.org/10.1016/j.ijfatigue. 2008.05.019

10. Olivier R, Ritter W (1979) Wöhlerlinienkatalog für Schweißverbindungen aus Baustählen - Teil 1: Stumpfstoß Einheitliche statistische Auswertung von Ergebnissen aus Schwingfestigkeitsversuchen. Deutscher Verband für Schweißtechnik e.V., Düsseldorf, DVS-report no. 56/I

11. Leitner M, Stoschka M, Schanner R, Eichlseder W (2012) Influence of high frequency peening on fatigue of high-strength steels. FME Transactions 40(3):99-104

12. Berg J, Stranghöner N (2016) Fatigue behaviour of high frequency hammer peened ultra high strength steels. International Journal of Fatigue 82:35-48. https://doi.org/10.1016/j.ijfatigue.2015.08.012

13. Fricke W (2012) IIW recommendations for the fatigue assessment of welded structures by notch stress analysis: IIW-2006-09. Woodhead Publishing. https://oi.org/10.1533/9780857098566
14. Lawrence FV, Ho N-J, Mazumdar PK (1981) Predicting the fatigue resistance of welds. Annual Review of Materials Science 11:401425

15. Schubert R (1992) Spannungs-Dehnungs-Verhalten von simulierten WEZ-Gefügen und Schweißnähten unter zyklischer Belastung. Mater Werkst 23:162-170

16. Boroński D (2006) Cyclic material properties distribution in laserwelded joints. International Journal of Fatigue 28:346-354. https:// doi.org/10.1016/j.ijfatigue.2005.07.029

17. Boroński D (2015) Testing low-cycle material properties with micro-specimens. Materials Testing 57(2):165-170. https://doi.org/ $10.3139 / 120.110693$

18. Sołtysiak R, Boroński D (2015) Strain analysis at notch root in laser welded samples using material properties of individual weld zones. International Journal of Fatigue 74:71-80. https://doi.org/10.1016/ j.ijfatigue.2014.12.004

19. Möller B, Wagener R, Kaufmann H, Melz T (2015) Fatigue life and cyclic material behavior of butt welded high-strength steels in the LCF regime. Materials Testing 57(2):141-148. https://doi.org/10. $3139 / 120.110691$

20. Ahrend E (2018) Kurzzeitfestigkeit von Schweißverbindungen: Ein Verfahren zur Parameteridentifikation lokaler zyklischer Spannungs-Dehnungs-Kurven bei Werkstoffinhomogenitäten auf Basis digitaler Bildkorrelation. Dissertation, Technische Universität Darmstadt, TUprints, Darmstadt

21. Saiprasertkit K (2012) Strain based fatigue strength evaluation of beam-to-column connections in steel bridge bents. Dissertation, Tokyo Institute of Technology

22. Saiprasertkit K, Hanji T, Miki C (2012) Local strain estimation method for low- and high-cycle fatigue strength evaluation. International Journal of Fatigue 40:1-6. https://doi.org/10.1016/j. ijfatigue.2012.01.021

23. Saiprasertkit K, Hanji T, Miki C (2012) Fatigue strength assessment of load-carrying cruciform joints with material mismatching in lowand high-cycle fatigue regions based on the effective notch concept. International Journal of Fatigue 40:120-128. https://doi.org/10. 1016/j.jijatigue.2011.12.016

24. Saiprasertkit K (2013) Fatigue strength assessment of load carrying cruciform joints in low and high cycle fatigue region based on effective notch concept. IIW document XIII-2456-13. International Institute of Welding

25. DIN EN 10025-2 (2011) Hot rolled products of structural steels part 2: technical delivery conditions for non-alloy structural steels; German version prEN 10025-2:2011. Beuth Verlag GmbH, Berlin

26. DIN EN 10025-3 (2011) Hot rolled products of structural steels part 3: technical delivery conditions for normalized/normalized rolled weldable fine grain structural steels; German version prEN 10025-3:2011. Beuth Verlag GmbH, Berlin

27. DIN EN 10027-1 (2017) Designation systems for steels - part 1: steel names; German version EN 10027-1:2016. Beuth Verlag $\mathrm{GmbH}$, Berlin

28. DIN EN 10025-6 (2011) Hot rolled products of structural steels part 6: technical delivery conditions for flat products of high yield strength structural steel in the quenched and tempered conditions; German version prEN 10025-6:2011. Beuth Verlag GmbH, Berlin

29. DIN EN 10025-4 (2011) Hot rolled products of structural steels part 4: technical delivery conditions for thermomechanical rolled weldable fine grain structural steels; German version prEN 100254:2011. Beuth Verlag GmbH, Berlin

30. Schröter F (2003) Höherfeste Stähle für den Stahlbau - Auswahl und Anwendung. Bauingenieur no 9, p. 420-432

31. Melz T, Möller B, Baumgartner J, Ummenhofer T, Herion S, Hrabowski J, Henkel J, Boos B, Baier E (2015) Erweiterung des örtlichen Konzeptes zur Bemessung von LCF-beanspruchten geschweißten Kranstrukturen aus hochfesten Stählen. 
Forschungsbericht P 900, Forschungsvereinigung Stahlanwendungen e.V., Düsseldorf

32. Voestalpine Steel Division: alform ${ }^{\circledR}$ - Hot-rolled cut sheets alform ${ }^{\circledR}$ X-treme: Data sheet. August 2013

33. Möller B, Baumgartner J, Wagener R, Kaufmann H, Melz T (2015) Bemessung zyklisch beanspruchter Schweißverbindungen aus höchst- und ultrahochfesten Stählen. Stahlbau 84(9):620-628. https://doi.org/10.1002/stab.201510303

34. Möller B, Baumgartner J, Wagener R, Kaufmann H, Melz T (2017) Low cycle fatigue life assessment of welded high-strength structural steels based on nominal and local design concepts. International Journal of Fatigue 101:192-208. https://doi.org/10.1016/j. ijfatigue.2017.02.014

35. Stahl-Eisen-Prüfblatt (SEP) 1240 (2006) Testing and documentation guideline for the experimental determination of mechanical properties of steel sheets for CAE-calculations, Stahlinstitut VDEh, 1st Edition

36. Möller B, Wagener R, Hrabowski J, Ummenhofer T, Melz T (2015) Fatigue life of welded high-strength steels under Gaussian loads. Procedia Engineering 101:293-301. https://doi.org/10.1016/j. proeng.2015.02.035

37. Spindel JE, Haibach E The method of maximum likelihood applied to the statistical analysis of fatigue data including run-outs. S. E. E. International Conference 3-6 April 1978; Special print from the lecture volume "Applications of Computers in Fatigue", p. 7.1-7.23

38. Basquin $\mathrm{OH}$ (1910) The exponential law of endurance tests, American society test. Materials Proc 10:625-630

39. Coffin LA (1954) A study of the effects of cyclic thermal stress on a ductile metal. Transactions ASME (76):931-950

40. Manson SS (1965) Fatigue: a complex subject - some simple approximations. Exp Mech 5(7):193-226

41. Morrow JD (1965) Cyclic plastic strain energy and fatigue of metals, Internal Friction, Damping and Cyclic Plasticity. Special Technical Publication No. 378, ASTM, 45-87

42. Wagener R (2007) Zyklisches Werkstoffverhalten bei konstanter und variabler Beanspruchungsamplitude. Dissertation Technische Universität Clausthal, Papierflieger Verlag, Clausthal-Zellerfeld

43. Ramberg W, Osgood WR (1943) Description of stress-strain curves by three parameters, Technical Report Technical Note No. 902, NACA
44. Smith KN, Watson P, Topper TH (1970) A stress-strain function for the fatigue of metals. Journal of Materials 5(4):767-778

45. Bacher-Höchst M, Werner S, Sonsino CM (2001) Schwingfestigkeit kaltumgeformter Fügestellen von Aluminiumgehäusen für Bremsregelsysteme. DVM report 128 ,Fertigungsverfahren und Betriebsfestigkeit“, Schaffhausen, 85-104

46. Werner S (1999) Zur betriebsfesten Auslegung von Bauteilen aus AlMgSi 1 unter Berücksichtigung von hohen Mitteldehnungen und Spannungskonzentrationen. Dissertation, Technische Universität Darmstadt, Technical report FB-217, Darmstadt

47. Haibach E, Lehrke HP (1975) Das Verfahren der AmplitudenTransformation. Fraunhofer LBF, Darmstadt, Technical report FB-125

48. Vormwald M (1989) Anrißlebensdauervorhersage auf Basis der Schwingbruchmechanik für kurze Risse. Dissertation, Technische Hochschule Darmstadt, Darmstadt

49. Fiedler M, Wächter M, Varfolomeev I, Vormwald M, Esderts A (2019) Richtlinie Nichtlinear - Rechnerischer Festigkeitsnachweis für Maschinenbauteile unter expliziter Erfassung nichtlinearen Werkstoffverformungsverhaltens - Für Bauteile aus Stahl, Stahlguss und Aluminiumknetlegierungen. FKM-Richtlinie, VDMA, 1st Edition, Frankfurt/Main

50. Bergmann J (1983) Zur Betriebsfestigkeitsmessung gekerbter Bauteile auf Grundlage der örtlichen Beanspruchungen. Dissertation, Technische Universität Darmstadt

51. Seyfried B, Möller B, Knödel P, Wagener R, Ummenhofer T, Melz $T$ (2018) Anwendungspotential von Laserstrahl- und Laserhybridschweißnähten für Stumpfstoßverbindungen ultrahochfester Feinkornbaustähle. DVS report 344:376-384

52. Möller B Seyfried B, Wagener R, Knödel P, Melz T, Ummenhofer T (2019) Fatigue strength of laser welded butt joints made of highstrength fine-grained structural steels for the application in crane structures. Proceedings der European Steel Technology and Application Days (ESTAD), Düsseldorf, 335

Publisher's note Springer Nature remains neutral with regard to jurisdictional claims in published maps and institutional affiliations. 